\title{
Effect of Cd on serum osmolality, ion levels and hematological parameters of tilapia (Oreochromis niloticus) at different salinity levels
}

\author{
Pramita Adi Listiyani, Miftachul Shobirin, Eka Novianti, Bambang Irawan, Sucipto Hariyanto \\ and Agoes Soegianto $\mathbb{D}$
}

Department of Biology, Faculty of Sciences and Technology, Universitas Airlangga, Surabaya, Indonesia

\begin{abstract}
Effects of cadmium on serum osmolality, ion levels and hematological parameters of tilapia (Orechromis niloticus) were evaluated at different salinities. Serum osmolalities (SOs) in fish unexposed to $\mathrm{Cd}\left(0 \mathrm{mg} \mathrm{I}^{-1}\right)$ and exposed to $2.5 \mathrm{mg} \mathrm{Cd} \mathrm{I}^{-1}$ were not significantly different at salinities of 0,5 and $10 \mathrm{~g} \mathrm{I}^{-1}$, while at $15 \mathrm{~g} \mathrm{I}^{-1}$, SO was significantly higher than at 0,5 and $10 \mathrm{~g}$ $\mathrm{I}^{-1}$. Levels of $\mathrm{Na}^{+}$and $\mathrm{Cl}^{-}$in serum at salinities of 5,10 and $15 \mathrm{~g} \mathrm{I}^{-1}$ were not significantly different; but were significantly higher than those at $0 \mathrm{~g} \mathrm{I}^{-1}$ with and without $\mathrm{Cd}$. In media without $\mathrm{Cd}$, the lowest level of $\mathrm{K}^{+}$in serum occurred at $15 \mathrm{~g} \mathrm{I}^{-1}$ salinity, whereas levels of $\mathrm{K}^{+}$at 0,5 and $10 \mathrm{~g} \mathrm{I}^{-1}$ were not significantly different. The levels of $\mathrm{K}^{+}$in Cd-exposed fish at all salinities were not significantly different. At $0 \mathrm{~g} \mathrm{I}^{-1}$ salinity, hemoglobin, red blood cells, and hematocrit in Cd-exposed fish were significantly lower than controls. At salinities of 5, 10 and $15 \mathrm{~g} \mathrm{I}^{-1}$, levels in control and Cd-exposed fish were not significantly different indicating that higher salinity prevented $\mathrm{Cd}$-induced osmotic imbalance and hematological alterations.
\end{abstract}

ARTICLE HISTORY

Received 8 June 2017

Accepted 30 May 2018

KEYWORDS

Cadmium; Oreochromis niloticus; salinity; osmoregulation; serum ions; hematology

\section{Introduction}

Cadmium (Cd) is a non-degradable pollutant entering the environment from both anthropogenic activities and natural processes. The concentration of $\mathrm{Cd}$ in natural aquatic environment was $<0.1 \mu \mathrm{g} \mathrm{I}^{-1}$, however in heavily polluted waters, cadmium concentration was up to $2-16.1 \mathrm{mg} \mathrm{I}^{-1}$ (Cao et al. 2012). This metal can be accumulated in the aquatic biota including fish. Chronic contamination of freshwater and marine environments with $\mathrm{Cd}$, which is considered to be of severe and pervasive concern (Romeo et al. 2000), is reported frequently. Exposure to sub-lethal concentrations of $\mathrm{Cd}$ may cause biochemical and ionic disturbances or adaptive responses in blood and tissues of fish (Pelgrom et al. 1995), and alter the blood composition and immune mechanisms (Wendelaar Bonga and Lock 1992; Witeska 2005; Gabriel, Anyanwu, and Akinrotimi 2007).

Previous observations showed that toxic effects of metals depend on a range of biotic and abiotic factors (Erickson et al. 2008). As an abiotic factor, salinity exerts a significant effect on metal toxicity and accumulation. Toxicity of metals reduces with the increasing medium salinity (Erickson et al. 2008; Loro et al. 2012). Salinity affects metal bioavailability and uptake and its subsequent toxicity by competing with metal ions for binding to biological molecules (Bianchini et al. 2002). On the other hand, bioavailability and toxicity of metals may be also influenced by the physiology and osmoregulatory strategy of an organism (Bielmyer, Brix, and
Grosell 2008; Bielmyer and Grosell 2011). Freshwater teleosts actively combat diffusive losses of ions by taking up $\mathrm{Na}^{+}$and $\mathrm{Cl}^{-}$at the gill, whereas, the hypertonic environment of the saltwater-acclimated fish promotes active excretion of $\mathrm{Na}^{+}$and $\mathrm{Cl}^{-}$at the gill and stimulates ingestion of the surrounding waters, thereby relying on the gills and intestine for ionoregulation, osmoregulation and water balance (Marshall 2002).

Moreover, toxic effects of $\mathrm{Cd}$ on fish are persistent and inhibit activity of many enzymes such as $\mathrm{Ca}^{2+}{ }^{2}$-ATPase, $\mathrm{Na}^{+} / \mathrm{K}^{+}$-ATPase, $\mathrm{H}^{+}$-ATPase, and carbonic anhydrase present in the gills and kidney, which are involved in the uptake of ions and maintenance of ionic balance in freshwater fish (Verbost et al. 1988; Perry et al. 2003).

Tilapias (Oreochromis niloticus) tolerate a wide range of salinity. Their ability to thrive in different salinity environments makes them a robust aquaculture species (Sardella et al. 2004; Canonico et al. 2005). Tilapia can be cultured efficiently in freshwater, brackish water and seawater, which is greatly advantageous in the light of global shortage of freshwater representing one of the most severe global challenges of our times (Beuhler 2003). Current projections of global climate change forecast a salinity increase of as much as $9 \mathrm{~g} \mathrm{I}^{-1}$ in many parts of coastal water systems (Knowles and Cayan 2002). It means that many coastal areas will be inundated by brackish water. This significant salinity increase will have physiological effects on organisms inhabiting these ecosystems. Moreover, in regions, which are impacted by industrial, agricultural and

CONTACT Agoes Soegianto agoes_soegianto@unair.ac.id; soegiant@indo.net.id $\Theta$ Department of Biology, Faculty of Sciences and Technology, Universitas Airlangga, Surabaya, Indonesia

(c) 2018 Nature Research Centre 